\title{
INBREEDING IN TWO MAIZE SUBPOPULATIONS SELECTED FOR TASSEL SIZE
}

\author{
Austeclinio L. de Farias Neto; José Branco de Miranda Filho²* \\ ${ }^{1}$ Embrapa Cerrados, Rodovia BR 020, km 17 - CEP: 73301-970 - Planaltina, DF. \\ ${ }^{2}$ Depto. de Genética - USP/ESALQ, C.P. 83 - CEP: 13400-970 - Piracicaba, SP. \\ ${ }^{*}$ Corresponding author <jbmirand@carpa.ciagri.usp.br>
}

\begin{abstract}
The present work was based on the evaluation of full sib and $S_{1}$ progenies from the maize (Zea mays L.) population ESALQ-PB1 after six cycles of divergent selection for tassel size. The following traits were analyzed: plant height , ear height, tassel branch number, tassel length, and tassel weight. For all traits, the experimental units were means of three plants per plot. Progenies were evaluated in eleven experiments (completely randomized blocks) with three replications in Piracicaba - SP, Brazil. Means of inbred $\left(m_{1}\right)$ and non-inbred $\left(m_{0}\right)$ progenies were used to estimate inbreeding depression $\left(I=m_{1}-m_{0}\right)$ and the contribution of homozygotes $\left(\mu_{0}+a^{*}\right)$ and heterozygotes $\left(d^{*}\right)$ to the population mean. Considering the five traits under study, inbreeding depression varied from 1.9 to $15.9 \%$ but significance for that effect was detected only for plant height. Plant traits exhibited higher depression than tassel traits; and tassel branch number seems to be more sensitive to inbreeding than the other two tassel traits. Except for plant height, it was apparent that inbreeding depression was higher in the subpopulation negatively selected for tassel size (T-). Estimates of $A=\mu_{0}+a^{*}$ and $\mathrm{d}^{*}$ indicate a smaller effect of dominance deviations for all traits, as compared to the contribution of homozygotes. Significant variability among progenies was detected in most instances.
\end{abstract}

Key words: inbreeding depression, divergent selection, tassel characters

\section{ENDOGAMIA EM DUAS SUBPOPULAÇÕES DE MILHO SELECIONADAS PARA TAMANHO DO PENDÃO}

\begin{abstract}
RESUMO: O presente trabalho foi baseado na avaliação de progênies de irmãos germanos e $S_{1}$ da população de milho (Zea mays L.) ESALQ-PB1 depois de seis ciclos de seleção divergente para tamanho do pendão. Os seguintes caracteres foram analisados: altura da planta, altura da espiga, número de ramificações do pendão, comprimento do pendão e peso do pendão. Para todos os caracteres, as unidades experimentais foram médias de três plantas por parcela. As progênies foram avaliadas em onze experimentos (blocos completamente casualizados) com três repetições em Piracicaba - SP, Brasil. As médias das progênies endogâmicas $\left(m_{1}\right)$ e não endogâmicas $\left(m_{0}\right)$ foram usadas para estimar a depressão por endogamia $\left(I=m_{1}-m_{0}\right)$ e a contribuição de homozigotos $\left(\mu_{0}+\mathrm{a}^{*}\right)$ e heterozigotos $\left(\mathrm{d}^{*}\right)$ para a média populacional. Considerando os cinco caracteres sob estudo, a depressão por endogamia variou de 1,9 to $15,9 \%$ mas somente para altura da planta foi detectada significância para aquele efeito. Os caracteres da planta exibiram maior depressão do que os caracteres do pendão; e o número de ramificações do pendão parece ser mais sensível à endogamia do que os outros caracteres do pendão. Com exceção de altura da planta, foi evidente que a depressão por endogamia foi maior na subpopulação selecionada negativamente para tamanho do pendão ( $(T-)$. As estimativas de $A=\mu_{0}+$ $\mathrm{a}^{*}$ e $\mathrm{d}^{*}$ indicam um menor efeito dos desvios de dominância para todos os caracteres, quando comparados com a contribuição dos homozigotos. Foi detectada variabilidade significativa entre progênies na maioria dos casos.
\end{abstract}

Palavras-chave: depressão por endogamia, seleção divergente, caracteres do pendão

\section{INTRODUCTION}

Inbreeding is the cross between related individuals, leading to an increase in the frequency of homozygotes and a decrease of heterozygotes. The negative effect of inbreeding, known as inbreeding depression, is a reduction in the mean of quantitative traits, related either to reproduction capacity or physiological efficiency, and is a consequence of recessive deleterious alleles (Falconer, 1964; Miranda Filho, 1999).

Under a breeding viewpoint, inbreeding can be useful either for the development of inbred lines to be used in hybrid crosses or in recurrent selection with inbred progenies for the development of improved populations (Paterniani \& Miranda Filho, 1987; Hallauer \& Miranda Filho, 1995). Cockerham (1983) showed that recurrent selection under inbreeding could be affected negatively by the component $D_{1}$, that is the covariance between additive and dominance effects in the homozygotes. In fact, because $D_{1}$ is a covariance it can be negative for alleles at low frequency, and then affect negatively the gain from selection (Lamkey \& Hallauer, 1992). On the other hand, recurrent selection under inbreeding allows selection against deleterious and lethal or sublethal recessives (Hallauer, 1980). This aspect is particularly important in Brazil, where many broad base maize populations have 
exhibited a high genetic load, resulting in a high inbreeding depression when submitted to inbreeding (Lima et al., 1984; Marques, 1988).

Hallauer \& Miranda Filho (1995) pointed out that despite the extremely high number of inbred lines developed in maize throughout the world, estimates of inbreeding depression for several quantitative traits are surprisingly low. The same authors reported inbreeding depression of 57.6 grams per plant for grain yield for $50 \%$ expected homozygosity, on the average of several estimates; for plant height and ear height, average inbreeding depressions were $22.0 \mathrm{~cm}$ and $15.6 \mathrm{~cm}$, respectively. Lima et al. (1984) reported inbreeding depression in 32 Brazilian maize populations, varying from 27.0 to $59.9 \%$ for grain yield, 6.6 to $20.3 \%$ for plant height and 6.9 to $27.4 \%$ for ear height. They also observed that populations derived from inbred lines exhibited lower inbreeding depression (34\% less) than openpollinated varieties that were never submitted to inbreeding, thus corroborating Hallauer (1980) on the effectiveness of inbreeding for selection against recessive deleterious.

The inbreeding effects on tassel size (tassel branch number) were estimated by Kassouf \& Miranda Filho (1986) as $15.3 \%$ in the maize population ESALQ-PB1 and by Nass \& Miranda Filho (1995) as $19.4 \%$ and $12.7 \%$ in two semi-exotic populations. In this work, full-sib and inbred $\left(S_{1}\right)$ progenies of two subpopulations divergently selected for tassel size were used for estimating the effects of inbreeding on tassel and plant characters.

\section{MATERIAL AND METHODS}

The base population ESALQ-PB1 was submitted to six cycles of divergent selection for tassel size, thus generating two subpopulations, which were designated by ESALQ-PB1 $(\mathrm{T}+)$ and ESALQ-PB1 (T-) for increasing and decreasing the trait, respectively. ESALQ-PB1 is a composite formed from crosses between seven short plant varieties (Miranda Filho, 1974). The divergent selection program initiated in 1979/80 in Piracicaba, São Paulo State, Brazil, based on the performance of 147 half-sib families evaluated in three $7 \times 7$-lattice experiments with four replications. The following five cycles were completed under mass selection for both sexes (biparental crosses between selected plants). In the sixth cycle, selfing was also used for the development of $S_{1}$ progenies besides de full-sib progenies obtained in the biparental crosses. The four sets and their respective number of progenies are shown in TABLE 1.

TABLE 1 - Number of FS (full-sib) and $S_{1}$ progenies in several experiments in Piracicaba (SP).

\begin{tabular}{|c|c|c|c|c|c|}
\hline \multirow{2}{*}{$\begin{array}{c}\text { Subpopulations } \\
\text { ESALQ-PB1(T+)FS }\end{array}$} & \multicolumn{4}{|c|}{$\begin{array}{c}\text { Number of progenies in } \\
\text { experiments }\end{array}$} & \multirow{2}{*}{$\begin{array}{r}\text { Total } \\
180\end{array}$} \\
\hline & 50 & 51 & 51 & 28 & \\
\hline ESALQ-PB1(T-)FS & 57 & 56 & 55 & - & 168 \\
\hline ESALQ-PB1(T+)S1 & 54 & - & - & - & 54 \\
\hline ESALQ-PB1(T-)S1 & 49 & 49 & 38 & - & 136 \\
\hline
\end{tabular}

The total number of progenies was divided into several experiments following the completely randomized block design with three replications in Piracicaba - SP, Brazil, in November/1994. Plots were $4 \mathrm{~m}$ long under spacing of $0.90 \mathrm{~m}$ between rows and $0.20 \mathrm{~m}$ between plants within rows. The following traits were analyzed: plant height $(\mathrm{cm})$, ear height $(\mathrm{cm})$, tassel branch number, tassel length $(\mathrm{cm})$, and tassel weight $(\mathrm{g})$. For all traits, the experimental units were plot means of three plants per plot. The commercial hybrid G-85 was used as check.

For each experiment, the analysis of variance followed the model of the completely randomized block design, i.e., $Y_{i j}=m+p_{i}+b_{i}+e_{i j}$, where $Y_{i j}$ is the observed mean of the $i^{\text {th }}$ progeny in the $j^{\text {th }}$ replication; $p_{i}$ is a random progeny effect; $b_{i}$ is a random block effect; and $e_{i j}$ is the experimental error term, assumed to be normally distributed with mean 0 and variance $\sigma^{2}$ for testing hypothesis through the F-test. Pooling the respective sums of squares combined the individual analyses representing the same subpopulation.

Inbreeding depression (I) for each trait was obtained by the contrast $\mathrm{I}=\mathrm{m}_{1}-\mathrm{m}_{0}$, where $\mathrm{m}_{1}$ and $\mathrm{m}_{0}$ are population means represented by inbred $\left(S_{1}\right)$ and noninbred (full-sib) progenies, respectively. Also, $\mathrm{m}_{0}=\mu_{0}+$ $a^{*}+d^{*}$ and $m_{1}=\mu_{0}+a^{*}+\frac{1}{2} d^{*} ; \mu_{0}=\sum_{k} \mu_{k}$ represents the mean of homozygotes for each locus summed over all loci; $a^{*}$ is the overall contribution (deviation from $\mu_{0}$ ) of the homozygous genotypes; and $\mathrm{d}^{*}$ is the overall contribution of heterozygotes. So, the quantities $A=\mu_{0}+a^{*}$ and $d^{*}$ were estimated by $\hat{A}=2 m_{1}-m_{0}$ and $\hat{d}^{*}=2\left(m_{0}-m_{1}\right)$

\section{RESULTS AND DISCUSSION}

For all traits, means of inbred $\left(\mathrm{S}_{1}\right)$ progenies were smaller than for non-inbred (full-sib) progenies. This phenomenon is known as inbreeding depression and depends directly on the level of dominance so that no changes in the mean are expected under inbreeding when genes controlling the trait follow a strictly additive model (Falconer, 1964). Therefore, a higher depression under inbreeding is expected for traits under the control of higher levels of dominance. Considering the five traits under study, inbreeding depression varied from 1.9 to $15.9 \%$ but significance for that effect was detected only for plant height (TABLE 2). It is also clear that plant traits exhibited higher depression than tassel traits; and tassel branch number seems to be more sensitive to inbreeding than the other two tassel traits. Except for plant height, it was apparent that inbreeding depression was higher in the subpopulation negatively selected for tassel size (T-). Such effects may limit the use of the subpopulation ESALQ-PB1 $(\mathrm{T}-$ ) as source of inbred lines to be used in hybrid crosses, mainly if the lines are to be used as male parents. Nevertheless, Stebbins (1957) pointed out that the inbreeding effect in cross-pollinated species is higher in the first generations and tend to decrease in the next generations of selfing. This is a consequence of the 
reduction in the genetic load represented by recessive deleterious and semi-lethal genes that are brought about by inbreeding (Miranda Filho, 1999). It was also expected that inbreeding depression should be smaller in the divergently selected subpopulations, as a consequence of the increase in the level of homozygosity caused by selection, when compared with the original population.

Kassouf \& Miranda Filho (1986) also reported inbreeding depression of $15.3 \%$ for tassel size in the base population ESALQ-PB1. Nass \& Miranda Filho (1995) reported on inbreeding depression of the order of 13.7 and $12.8 \%$ for plant height, 15.9 and $14.2 \%$ for ear height and 19.4 and $12.7 \%$ for tassel branch number in the semi-exotic populations EE-1 and EC-4, respectively. A smaller depression for tassel branch number $(11.1 \%)$ was reported by San Vicente \& Hallauer (1993). Hallauer \& Miranda Filho (1995) reported on inbreeding depression of $10 \%$ for plant height and $15 \%$ for ear height for $50 \%$ expected homozygosity in the maize population BSSS.

Miranda Filho \& Andrade (2000) estimated means of thirteen quantitative traits in the original population ESALQPB1. Although the results are not directly comparable, tassel weight $(5.87 \mathrm{~g})$ and tassel length $(40.9 \mathrm{~cm})$ did not differ greatly from the means shown in TABLE 2 . However, tassel branch number was strongly affected by the divergent selection for tassel size. In fact, the original population mean of 18.4 (Miranda Filho \& Andrade, 2000) changed to 35.2 (noninbred) and 32.2 (inbred) in the positive selection $\left(T_{+}\right)$and to 7.4 (non-inbred) and 6.3 (inbred) in the negative selection ( $T-$ ).

Estimates of $A=\mu_{0}+a^{*}$ (expected mean of a random sample of completely homozygous lines) and $d^{*}$ (overall contribution of heterozygotes to the mean), indicate a smaller effect of dominance deviations for all traits, as compared to the contribution of homozygotes (TABLE 2).

A similar conclusion was reported by Nass \& Miranda Filho (1995), except for yield traits where the effects of dominance were more expressive, although epistatic effects in depression caused by strongly deleterious alleles cannot be ruled out.

A complementary set of information referred to the observed variability among progenies, which showed to be significant $(P<0.01)$ in most of the instances (TABLE 3$)$. Exceptions representing non-significant variation were due to ear height in the subpopulation ESALQ-PB1 $(T+) S_{1}$ and for tassel weight in the subpopulation ESALQ-PB1 (T-)FS. A small variability should be expected in some instances, as a consequence of the effect of six cycles of divergent selection for tassel size. Apparently, for plant height and ear height, a higher expression of genetic variability occurred in the inbred progenies, although higher environmental effects represented by the error mean squares were also detected in that cases. A very high difference in the expression of variability was observed for tassel branch number, the trait that was submitted to divergent selection. For both types of progenies the higher mean squares were for the subpopulation selected for larger tassels. Because the large difference between means of divergently selected populations, a scale effect on the magnitude of the variances (mean squares) must be taken into account. No great differences in the expression of variability were observed for the other tassel traits.

TABLE 2 - Observed means of five traits in inbred $\left(m_{1}\right)$ and non-inbred $\left(m_{0}\right)$ subpopulations of ESALQ-PB1 and estimates of the inbreeding depression (I), the expected mean of homozygous lines $\left(A=\mu_{0}+a^{*}\right)$ and overall contribution of heterozygotes $\left(d^{*}\right)$

\begin{tabular}{|c|c|c|c|c|c|c|}
\hline Subpopulations & $\mathrm{m}_{0}$ & $\mathrm{~m}_{1}$ & I & $1 \%$ & $A=\mu_{0}+a^{*}$ & $\hat{\mathrm{d}}^{*}$ \\
\hline & \multicolumn{6}{|c|}{ Plant height $(\mathrm{cm})$} \\
\hline ESALQ-PB1(T+) & 197.0 & 165.7 & $-31.3^{*}$ & -15.9 & 134.4 & 62.6 \\
\hline ESALQ-PB1(T-) & 187.6 & 159.6 & $-28.0^{*}$ & -14.9 & 131.6 & 56.0 \\
\hline \multirow[t]{2}{*}{ Hybrid check } & 169.7 & & & & & \\
\hline & \multicolumn{6}{|c|}{ Ear height $(\mathrm{cm})$} \\
\hline ESALQ-PB1(T+) & 107.9 & 97.8 & $-10.1^{\text {ns }}$ & -9.3 & 87.7 & 20.2 \\
\hline ESALQ-PB1(T-) & 87.7 & 76.4 & $-11.3^{\text {ns }}$ & -12.9 & 65.1 & 22.6 \\
\hline \multirow[t]{2}{*}{ Hybrid check } & 85.2 & & & & & \\
\hline & \multicolumn{6}{|c|}{ Tassel branch number } \\
\hline ESALQ-PB1(T+) & 35.2 & 32.2 & $-3.0^{n s}$ & -8.5 & 29.2 & 6.0 \\
\hline ESALQ-PB1(T-) & 7.4 & 6.3 & $-1.1^{\mathrm{ns}}$ & -14.9 & 5.2 & 2.2 \\
\hline \multirow[t]{2}{*}{ Hybrid check } & 19.4 & & & & & \\
\hline & \multicolumn{6}{|c|}{ Tassel leng th (cm) } \\
\hline ESALQ-PB1(T+) & 42.0 & 40.5 & $-1.5^{\mathrm{ns}}$ & -3.6 & 39.0 & 3.0 \\
\hline ESALQ-PB1(T-) & 41.8 & 38.2 & $-3.6^{\mathrm{ns}}$ & -8.6 & 34.6 & 7.3 \\
\hline \multirow[t]{2}{*}{ Hybrid check } & 43.6 & & & & & \\
\hline & \multicolumn{6}{|c|}{ Tassel weight (g) } \\
\hline ESALQ-PB1(T+) & 4.29 & 4.21 & $-0.08^{\text {ns }}$ & -1.9 & 4.13 & 0.16 \\
\hline ESALQ-PB1(T-) & 3.81 & 3.72 & $-0.09^{\text {ns }}$ & -2.4 & 3.63 & 0.18 \\
\hline Hybrid check & 3.53 & & & & & \\
\hline
\end{tabular}

"Significance $(P<0.05)$ by t-test; ns non-significant 
TABLE 3 - Mean squares in the analysis of variance for five traits in progenies of four subpopulations of ESALQ-PB1.

\begin{tabular}{|c|c|c|c|c|c|c|}
\hline Source of variation & $d f$ & $\begin{array}{l}\text { Plant } \\
\text { height }\end{array}$ & $\begin{array}{c}\text { Ear } \\
\text { height }\end{array}$ & $\begin{array}{c}\text { Tassel } \\
\text { branches }\end{array}$ & $\begin{array}{l}\text { Tassel } \\
\text { length }\end{array}$ & $\begin{array}{l}\text { Tassel } \\
\text { weight }\end{array}$ \\
\hline & & $\mathrm{cm}$ & $\mathrm{cm}$ & & $\mathrm{cm}$ & g \\
\hline & & \multicolumn{5}{|c|}{ ESALQ-PB1(T+)FS } \\
\hline Progenies & 176 & $528.46^{\star *}$ & $346.97^{\star *}$ & $52.199^{* \star}$ & $16.415^{\star \star}$ & $0.1016^{* \star}$ \\
\hline Pooled error & 352 & 134.43 & 131.78 & 26.470 & 10.890 & 0.0707 \\
\hline \multirow[t]{2}{*}{ CV\% } & & 5.9 & 10.6 & 14.6 & 7.8 & 6.2 \\
\hline & & \multicolumn{5}{|c|}{ ESALQ-PB1(T-)FS } \\
\hline Progenies & 165 & $570.88^{* *}$ & $323.64^{* *}$ & $10.143^{* *}$ & $22.697^{* *}$ & $0.0170^{\text {ns }}$ \\
\hline Pooled error & 330 & 151.65 & 134.60 & 4.168 & 7.773 & 0.0131 \\
\hline \multirow[t]{2}{*}{ CV\% } & & 6.6 & 13.2 & 27.6 & 6.7 & 3.0 \\
\hline & & \multicolumn{5}{|c|}{ ESALQ-PB1(T+)S1 } \\
\hline Progenies & 53 & $616.39^{* \star}$ & $735.29^{\text {ns }}$ & $95.243^{\star *}$ & $23.611^{\star *}$ & $0.1150^{* \star}$ \\
\hline Pooled error & 106 & 246.83 & 631.18 & 30.840 & 7.475 & 0.0374 \\
\hline \multirow[t]{2}{*}{ CV\% } & & 9.5 & 25.2 & 17.3 & 6.7 & 4.6 \\
\hline & & \multicolumn{5}{|c|}{ ESALQ-PB1(T-)S1 } \\
\hline Progenies & 133 & $904.28^{* *}$ & $485.54^{* *}$ & $21.998^{* *}$ & $33.241^{* *}$ & $0.1701^{\text {** }}$ \\
\hline Pooled error & 266 & 298.66 & 174.92 & 6.765 & 8.680 & 0.0934 \\
\hline CV\% & & 10.8 & 17.3 & 41.3 & 7.7 & 8.2 \\
\hline
\end{tabular}

\section{REFERENCES}

COCKERHAM, C.C. Covariance of relatives from self-fertilization. Crop Science, v.23, p.1177-1180, 1983.

FALCONER, D.S. Introduction to quantitative genetics. 2.ed. New York: Ronald Press, 1964.

HALLAUER, A.R. Relation of quantitative genetics to applied maize breeding. Brazilian Journal of Genetics, v.3, p.207-233, 1980.

HALLAUER, A.R.; MIRANDA FILHO, J.B. Quantitative genetics in maize breeding. 2.ed. Ames: lowa State University Press, 1995.

KASSOUF, M.L.; MIRANDA FILHO, J.B. Variabilidade e endogamia na população de milho ESALQ-PB1. In: CONGRESSO NACIONAL DE MILHO E SORGO, 15., Maceió, 1984. Anais. Brasília: EMBRAPA, 1986. p.119-131.

LAMKEY, K.R.; HALLAUER, A.R. Fifty cycles of recurrent selection in the lowa Stiff Stalk Synthetic. Maydica, v.37, p.19-27, 1992.

LIMA, M.; MIRANDA FILHO, J.B.; GALLO, P.B. Inbreeding depression in Brazilian populations of maize (Zea mays L.). Maydica, v.29, p.203-215, 1984.

MARQUES, J.R.B. Seleção recorrente com endogamia em duas populações de milho (Zea mays L.). Piracicaba, 1988. 145p. Dissertação (Mestrado) - Escola Superior de Agricultura "Luiz de Queiroz", Universidade de São Paulo.

MIRANDA FILHO, J.B. Cruzamentos dialélicos e síntese de compostos de milho (Zea mays L.) com ênfase na produtividade e no porte da planta. Piracicaba, 1974. 116p. Tese (Doutorado) - Escola Superior de Agricultura "Luiz de Queiroz", Universidade de São Paulo.
MIRANDA FILHO, J.B. Inbreeding depression and heterosis. In: COORS, J.G.; PANDEY, S. (Ed.) Genetic and exploitation of heterosis in crops. Madison: American Society Agronomy, 1999. p.69-80.

MIRANDA FILHO, J.B.; ANDRADE, J.A.C. Quantitative variation in the maize population ESALQ-PB1. Genetics and Molecular Biology, v. 23, 2000. /In press/

NASS, L.L.; MIRANDA FILHO, J.B. Inbreeding depression rates of semi-exotic maize (Zea mays L.) populations. Brazilian Journal of Genetics, v.18, p.585-592, 1995.

PATERNIANI, E.; MIRANDA FILHO, J.B. Melhoramento de Populações. In: PATERNIANI, E.; VIÉGAS, G.P. (Ed.) Melhoramento e produção do milho. Campinas: Fundação Cargill, 1987. cap.6, p.215-274.

SAN VICENTE, F.N.; HALLAUER, A.R. Inbreeding depression rates of materials desirable from two groups of maize. Brazilian Journal of Genetics, v.16, p.989-1001, 1993.

STEBBINS, G.L. Self-fertilization and population variability in the higher plants. American Naturalist, v.91, p.337-354, 1957.

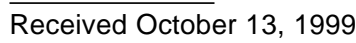

